\title{
Serratia entomophila-coated seed to improve ryegrass establishment in the presence of grass grubs
}

\author{
S.D. Young, R.J. Townsend, J. Swaminathan and M. O'Callaghan \\ AgResearch, Lincoln Research Centre, Private Bag 4749, Christchurch 8140, New Zealand \\ Corresponding author: sandra.young@agresearch.co.nz
}

\begin{abstract}
The entomopathogenic bacterium, Serratia entomophila, is an alternative to chemical control of grass grub (Costelytra zealandica) and is applied in a granule formulation to established pastures. Treatment of seed with microbial inoculants is an ideal mechanism for delivery and establishment of microbial control agents into the plant root zone where soil dwelling pests, such as grass grub, are located. Seed treatment with S. entomophila was tested in three glasshouse pot trials, for its ability to protect germinating ryegrass seedlings from grass grub damage. A range of larval densities was used and microbial seed treatment was compared with the insecticide imidacloprid. At medium larval densities (equivalent to 70 larvae $/ \mathrm{m}^{2}$ ), use of S. entomophila-coated seed resulted in $85 \%$ seedling establishment in comparison with $82 \%$ emergence from imidacloprid-treated seed. At a high larval density of $300 / \mathrm{m}^{2}$, where there was no establishment of untreated seed, $35-51 \%$ of seedlings established from $S$. entomophila-treated seed. Results suggest there is potential for seed coating to aid ryegrass establishment in autumn-sown pastures.
\end{abstract}

Keywords Serratia entomophila, grass grub, ryegrass, coated seed.

\section{INTRODUCTION}

The New Zealand grass grub (Costelytra zealandica) is a serious pest of pasture. The larvae feed on the roots of established grasses and on emerging seedlings in autumn-sown pastures (Chapman 1984). Chemical control measures to protect ryegrass seedlings from grass grub include the neonicitinoids imidacloprid $\left(\right.$ Gaucho ${ }^{\circledR}$, Bayer) and clothianidin $\left(\right.$ Poncho $^{\circledR}$, Bayer) applied as seed dressings.

Microbial control agents can be used as alternatives for, or in addition to, chemical insecticides. On organic farms, microbial control agents may be the only suitable option. The pathogenic bacterium Serratia entomophila, formulated as a granule, is sold in New Zealand (under the trade name bioshield ${ }^{\mathrm{TM}}$, Ballance Agri-Nutrients, Tauranga) for control of grass grub larvae in established pasture. The granules are applied beneath the surface of pasture where larvae are feeding using a seed drill. Infected grubs cease feeding within 3-4 days of infection and die within 3 weeks.

Seeds are an ideal delivery mechanism for the introduction of entomopathogenic microbes into the plant rhizosphere, as they allow targeted contact with and infection of insect pests and 
can introduce high populations of viable cells. Seed coating has been previously investigated as a means of introducing S. entomophila into the root zone of wheat (Young et al. 2009) and carrot (Wright et al. 2005) for the control of grass grub larvae.

This study examines the use of seed coating to deliver S. entomophila directly into the grass grub feeding zone. The efficacy of S. entomophila as a seed coating on ryegrass for control of grass grub larvae was compared with a commonly applied chemical alternative, imidacloprid, and with the use of the microbial control agent bioshield ${ }^{\mathrm{TM}}$.

\section{METHODS}

\section{Seed treatment}

Inoculum for preparation of seeds coated with S. entomophila was prepared as described previously (Young et al. 2009). Bacterial cells were concentrated by centrifugation and applied to seed using patented biopolymer technology (Swaminathan \& Jackson 2008). Imidacloprid was dressed onto seed in the laboratory at the recommended field rate of $5.8 \mathrm{ml} / \mathrm{kg}$ seed.

\section{Enumeration of bacteria on seed and in soil}

Bacteria present on seed were enumerated by mixing $1 \mathrm{~g}$ of seed with $10 \mathrm{ml}$ of Tween buffer (1.0 ml Tween 80 and $1.0 \mathrm{~g} \mathrm{Na}_{4} \mathrm{P}_{2} \mathrm{O}_{7} \cdot 10 \mathrm{H}_{2} \mathrm{O}$ ) and shaking at maximum speed for $10 \mathrm{~min}$ on a wrist action shaker. The coating suspension was then dilution plated onto Luria Bertani agar and the plates incubated at $30^{\circ} \mathrm{C}$ for $24 \mathrm{~h}$ before enumeration of colonies. Bacterial counts were in the range $1.4-6.5 \times 10^{9} \mathrm{cfu} / \mathrm{g}$ seed prior to planting.

Serratia entomophila was enumerated from soil by dilution plating onto selective media, using the method described by O'Callaghan \& Jackson (1993).

\section{Pot trials}

Three glasshouse pot trials were set up using 2-litre plastic pots $(15 \mathrm{~cm} \times 8 \mathrm{~cm})$ filled with sieved Templeton silt loam (approximately $1800 \mathrm{~g}$ dry weight). Three rows of 10 ryegrass seeds (Colosseum ${ }^{\circledR}$, PGG Wrightsons, Christchurch,
New Zealand) were planted to a depth of $1-2 \mathrm{~cm}$, approximating a $22 \mathrm{~kg} / \mathrm{ha}$ seeding rate. In trial 1 the treatments were: bare seed, S. entomophilacoated seed and seed coated but without bacteria as the control. All treatments were challenged at three larval densities: 0,3 and 9 larvae per pot, equivalent to 0,70 and $300 \mathrm{larvae} / \mathrm{m}^{2}$ (zero, moderateand severedamage-causing populations). In the second trial treatments were: bare seed and S. entomophila-coated seed at the same larval rates as trial 1 . In the third trial treatments were: bare seed, S. entomophila-coated seed, imidaclopridcoated seed, S. entomophila and imidacloprid combined coated seed, and bioshield ${ }^{\mathrm{TM}}$ granules sown together with bare seed. In all trials there were five replicates per treatment with the pots laid out in a randomised block design.

Field-collected, third instar grass grub larvae were pre-fed carrot cubes in trays over 3 days to select healthy, feeding individuals. Larvae were placed on the soil surface post-sowing and allowed to bury themselves in the soil. Any grubs remaining on the surface after 20 min were removed and replaced with healthy specimens to avoid using any larvae damaged by handling. Watering was carried out as required to maintain a soil moisture content of at least $15 \%$, equivalent to approximately $200 \mathrm{ml}$ per pot per week.

\section{Sampling}

The trial was conducted in an unheated glasshouse. After 7 weeks seedlings were counted and the total plant dry matter and numbers of surviving grubs recorded. Surviving grubs were characterised as either diseased or healthy by assessment of visual disease symptoms (Jackson et al. 1993). Numbers of S. entomophila bacteria in the soil (colony forming units/g dry soil) were calculated by dilution plating of soil onto selective media.

\section{Statistical analysis}

Seedling establishment numbers were analysed using Fisher's exact tests for trials 1 and 2, and logistic regression for trial 3 to compare interactions between treatment effects and numbers of larvae. Plant weights in trials 1 and 2 
were analysed using the 1-sample $t$ test with the null hypothesis of mean $=0$ where larvae were present, and in the absence of larvae by analysis of variance (ANOVA). Plant dry weights from trial 3 were analysed by ANOVA. Surviving grass grub numbers were analysed by Fisher's exact tests. Serratia entomophila cfu/g values were compared using either a negative binomial model or a quasi-Poisson model for treatment groups with at least one non-zero value and by Fisher's exact tests for comparison of treatment groups having all zero values with another group.

\section{RESULTS}

In trials 1 and 2 there were no significant differences between treatments in seedling establishment or final plant dry weights in the absence of grass grub larvae (Table 1). No seedlings survived in the bare seed or coated control treatments at larval densities of 70 or $300 / \mathrm{m}^{2}$. In the $S$. entomophila-coated seed treatments, around $72 \%$ of seedlings were established in both trials at medium larval density (70 larvae/ $\mathrm{m}^{2}$ ). At high larval densities (300 larvae $/ \mathrm{m}^{2}$ ), seedling establishment was reduced to 35 and $51 \%$ for trials 1 and 2 respectively.

In trials 1 and 2, plant dry matter weights from S. entomophila-coated seed were not significantly different between larval densities of 0 and $70 / \mathrm{m}^{2}$.
However, high larval densities resulted in significantly lower dry matter production than the medium larval densities in both trials (Table 1). Trial 1 was conducted in winter and trial 2 in early spring when average temperatures were higher, which may account for the difference in plant dry matter weights recorded between the two trials.

In the third trial, in the absence of larvae, the mean seedling establishment was $88.7 \%$ of seeds sown and the mean final dry matter weight $1.43 \mathrm{~g} /$ pot with no significant differences between treatments. Where the treatments were challenged by larvae, the best performing treatment, in terms of seeding establishment, was S. entomophilacoated seed, imidacloprid-dressed seed or a combination of both (82-85\%). These three seed treatments performed significantly better than either bioshield ${ }^{\mathrm{TM}}$ granules incorporated with bare seed $(42.7 \%)$ or bare seed $(20.7 \%)$. Bioshield $^{\mathrm{TM}}$ performed significantly better than bare seed (Table 2).

In trial 3, in the presence of grass grub larvae, the highest dry matter weights resulted from the seeds coated with S. entomophila, imidacloprid alone and in combination. The pots inoculated with bioshield ${ }^{\mathrm{TM}}$ granules yielded significantly lower dry matter weights than the three seed coating treatments (Table 2 ).

Table 1 Mean ryegrass seedling establishment (\%) and mean plant dry weights (g/pot) 49 days after sowing bare, coated (without Serratia entomophila) or Serratia entomophila-coated seed at three larval densities of Costelytra zealandica in trials 1 and 2.

\begin{tabular}{|c|c|c|c|c|c|}
\hline \multirow[b]{2}{*}{ Treatment } & \multirow{2}{*}{$\begin{array}{c}\text { Larvae } \\
\left(\text { no. } / \mathrm{m}^{2}\right)\end{array}$} & \multicolumn{2}{|c|}{ Seedling establishment } & \multicolumn{2}{|c|}{ Plant dry weights } \\
\hline & & Trial 1 & Trial 2 & Trial 1 & Trial 2 \\
\hline \multirow[t]{3}{*}{ Bare seed } & 0 & $92 a^{1}$ & $87 \mathrm{a}$ & $0.706 \mathrm{a}$ & $3.018 \mathrm{a}$ \\
\hline & 70 & 0 & 0 & 0.000 & 0.000 \\
\hline & 300 & 0 & 0 & 0.000 & 0.000 \\
\hline \multirow[t]{3}{*}{ Coated control } & 0 & $91 \mathrm{a}$ & $n t^{2}$ & $0.687 \mathrm{ab}$ & nt \\
\hline & 70 & 0 & nt & 0.000 & nt \\
\hline & 300 & 0 & nt & 0.000 & nt \\
\hline \multirow[t]{3}{*}{ S. entomophila } & 0 & $92 \mathrm{a}$ & $86 \mathrm{a}$ & $0.596 \mathrm{ab}$ & $3.274 \mathrm{a}$ \\
\hline & 70 & $72 \mathrm{~b}$ & $73 \mathrm{~b}$ & $0.459 \mathrm{~b}$ & $2.845 \mathrm{a}$ \\
\hline & 300 & $35 c$ & $51 \mathrm{c}$ & $0.186 \mathrm{c}$ & $1.590 \mathrm{~b}$ \\
\hline
\end{tabular}

${ }^{1}$ Values followed by the same letter within a column are not significantly different at $\mathrm{P}<0.01$.

${ }^{2} \mathrm{nt}$ - not tested. 
Table 2 Mean ryegrass seedling establishment (\%) and dry matter weights (g/pot) 49 days after sowing bare seed with and without biosheld ${ }^{\mathrm{TM}}$, or seed with either Serratia entomophila or imidacloprid or both in the presence of Costelytra zealandica larvae $\left(70\right.$ larvae $\left./ \mathrm{m}^{2}\right)$ in trial 3.

\begin{tabular}{llcc}
\hline Treatment & Rate & Establishment (\%) & Dry matter \\
\hline Bare seed & & $20.7 \mathrm{a}^{1}$ & $0.19 \mathrm{a}$ \\
bioshield $^{\mathrm{TM}}$ & $30 \mathrm{~kg} / \mathrm{ha}$ & $42.7 \mathrm{~b}$ & $0.50 \mathrm{~b}$ \\
S. entomophila & $6.50 \times 10^{9} \mathrm{cfu} / \mathrm{g}$ & $85.3 \mathrm{c}$ & $1.08 \mathrm{c}$ \\
Imidacloprid & $5.80 \mathrm{ml} / \mathrm{kg}$ & $82.0 \mathrm{c}$ & $1.12 \mathrm{c}$ \\
S. entomophila+imidacloprid & as above & $82.7 \mathrm{c}$ & $1.41 \mathrm{c}$ \\
\hline
\end{tabular}

${ }^{1}$ Values followed by the same letter within a column are not significantly different at $\mathrm{P}<0.001$.

\section{Grass grub survival}

In trial 1 there were no significant treatment effects on numbers of surviving healthy grubs at the lower rate of 70 larvae $/ \mathrm{m}^{2}$ (Table 3). At the high larval density, there was a significant reduction in the number of larvae recovered from the pots with S. entomophila-coated seeds (Table $3)$. In trial 2, there were no significant differences in the number of surviving larvae at either rate.

In trial 3, no surviving healthy larvae were recovered from the S. entomophila, S. entomophila plus imidacloprid or imidacloprid seed treatments. In the bare seed treatment there were seven surviving larvae and there were two in the bioshield $^{\mathrm{TM}}$ treatment.

\section{Serratia entomophila in soil}

In trials 1 and 2 , at the larval rate of $70 / \mathrm{m}^{2}$, significantly more bacteria were recovered from the soil in the S. entomophila-coated treatments than from the non $S$. entomophila-coated treatment. At the higher rate of 300 larvae $/ \mathrm{m}^{2}$, S. entomophila were recovered from the bare seed treatment; these bacteria were possibly introduced to the pots by the field-collected larvae but were evidently non-pathogenic strains as there was no inhibition of grass grubs in this treatment, resulting in zero plant establishment.

\section{Serratia entomophila survival on seed}

Samples of the S. entomophila-coated seed from trial 3 were stored at $20^{\circ} \mathrm{C}$, and sampled at 2 and 4 weeks after coating. From initial counts of 5.2-6.5 $\times 10^{9}$ colony forming units/g, the bacterial counts decreased to $2.0-0.88 \times 10^{7} \mathrm{cfu} / \mathrm{g}$ over 4 weeks (Table 5 ).

\section{DISCUSSION}

Previous work on application of S. entomophila as a seed coating to control grass grub in carrot (Wright et al. 2005) and wheat (Young et al. 2009) has demonstrated improved seedling establishment in the presence of grass grub larvae. In the pot trials reported here, coating of ryegrass seed with $S$. entomophila significantly improved establishment of ryegrass seedlings in the presence of grass grub larvae at densities that would typically result in moderate to severe pasture damage in the field. Serratia entomophilacoated seed performed as well as seed dressed with imidacloprid, and in these short term pot trials there was no significant advantage in combining S. entomophila with imidacloprid.

The high density grub treatment used in the pot trials (equivalent to 300 larvae $/ \mathrm{m}^{2}$ ) far exceeds the population density considered safe for sowing new pasture. At this larval density, the recommendation would normally be to carry out two or three surface workings prior to re-sowing, which would kill 40-70\% of the larvae (van Toor 1996). Thus it is unlikely that S. entomophilatreated seed would be used under this intense level of feeding pressure in the field.

Serratia entomophila used as a seed coating provided better protection of young seedlings than application of bioshield ${ }^{\mathrm{TM}}$ granules in combination with bare seed. This result is not unexpected as within the confined space in pots 
Table 3 Number of surviving healthy Costelytra zealandica larvae per treatment with bare, coated (without Serratia entomophila) or Serratia entomophila-coated seed at equivalent field rates of 70 or 300 larvae $/ \mathrm{m}^{2}$.

\begin{tabular}{|c|c|c|c|c|}
\hline \multirow[b]{2}{*}{ larvae $/ \mathrm{m}^{2}$} & \multicolumn{2}{|c|}{ Trial 1} & \multicolumn{2}{|c|}{ Trial 2} \\
\hline & 70 & 300 & 70 & 300 \\
\hline Bare seed & $10 \mathrm{a}^{1}$ & $21 \mathrm{a}$ & $4 \mathrm{a}$ & $7 a$ \\
\hline Coated control & $13 \mathrm{a}$ & $22 \mathrm{a}$ & $n t^{2}$ & nt \\
\hline S. entomophila & $4 \mathrm{a}$ & $6 \mathrm{~b}$ & $0 \mathrm{a}$ & $1 \mathrm{a}$ \\
\hline
\end{tabular}

${ }^{1}$ Values followed by the same letter within a column are not significantly different at $\mathrm{P}<0.01$.

${ }^{2} \mathrm{nt}$ - not tested.

Table 4 Mean Serratia entomophila (cfu/g dry soil) recovered from soil in S. entomophila or imidacloprid treatments under Costelytra zealandica larval densities of 70 or $300 / \mathrm{m}^{2}$ in Trials 1,2 and 3.

\begin{tabular}{|c|c|c|c|c|c|}
\hline \multirow[b]{2}{*}{ larvae $/ \mathrm{m}^{2}$} & \multicolumn{2}{|c|}{ Trial 1} & \multicolumn{2}{|c|}{ Trial 2} & \multirow{2}{*}{$\begin{array}{c}\text { Trial } 3 \\
70\end{array}$} \\
\hline & 70 & 300 & 70 & 300 & \\
\hline Bare seed & $0 \mathrm{~b}$ & $12.9 \mathrm{~b}$ & $0 \mathrm{~b}$ & $8339 a$ & $37 \mathrm{ab}$ \\
\hline Coated control & $0 \mathrm{~b}$ & $0 \mathrm{~b}$ & $\mathrm{nt}$ & nt & nt \\
\hline S. entomophila-coated seed & $8208 a^{1}$ & $3151 a$ & $1366 \mathrm{a}$ & $16204 \mathrm{a}$ & $1120 \mathrm{ab}$ \\
\hline bioshield $^{\mathrm{TM}}$ & $n t^{2}$ & nt & nt & $\mathrm{nt}$ & $2311 \mathrm{ab}$ \\
\hline Imidacloprid & nt & $\mathrm{nt}$ & nt & nt & $0 \mathrm{a}$ \\
\hline S. entomophila+imidacloprid & $\mathrm{nt}$ & $\mathrm{nt}$ & $\mathrm{nt}$ & $\mathrm{nt}$ & $583 \mathrm{~b}$ \\
\hline
\end{tabular}

${ }^{1}$ Values followed by the same letter within a column are not significantly different at $\mathrm{P}<0.01$.

${ }^{2} \mathrm{nt}$ - not tested.

Table 5 Serratia entomophila (cfu/g seed) survival at $20^{\circ} \mathrm{C}$.

\begin{tabular}{lccc}
\hline Treatment $^{1}$ & Initial & 2 weeks & 4 weeks \\
\hline S. entomophila & $6.5 \times 10^{9}$ & $5.3 \times 10^{8}$ & $8.8 \times 10^{6}$ \\
S. entomophila+imidacloprid & $5.2 \times 10^{9}$ & $2.0 \times 10^{8}$ & $2.0 \times 10^{7}$ \\
\hline
\end{tabular}

${ }^{1}$ These results were not analysed statistically as they were based on a single sample.

with no food source other than young seedlings, grass grubs would have been attracted to the germinating seed and young plant roots and brought into contact with $S$. entomophila very quickly, possibly before sufficient $S$. entomophila had been released from granules to cause grass grub infection. Enumeration of S. entomophila populations established in soil indicated that inoculation by seed or granule resulted in similar overall loadings of the inoculum per gram of soil, suggesting that the differing effectiveness of these two treatments in terms of seedling protection must be related to spatial distribution of inoculum within the pots. There could be potential for development of a bait product containing S. entomophila, which could attract the feeding larvae away from germinating seeds.

Field trials over a longer period are needed to ascertain the efficacy of these treatments with respect to pasture production in subsequent seasons. There is potential that inoculation of the soil with S. entomophila by either method is likely to result in more enduring grass grub control than use of chemical seed treatments, as the disease recycles in the grass grub population providing several seasons control (van Toor 1996). The 
compatibility of S. entomophila with imidacloprid on stored seed indicates there is potential to develop seed treatments with combinations of agents for enduring pasture protection.

There is an obvious market for S. entomophilacoated seed in the organic farming industry where grass grubs are as much of a threat to seedling emergence and establishment as in conventional farming. If further work confirms the results reported here in field scale trials, this application could also be utilised on non organic farms when direct drilling grass seed into sprayed out pasture or when over-sowing established pasture with top up seed in late summer and autumn into grass grub prone sites.

\section{ACKNOWLEDGEMENTS}

The authors thank Chikako van Koten for statistical analyses. This work was funded by the New Zealand Foundation for Research, Science and Technology Contract C10X0706.

\section{REFERENCES}

Chapman RB 1984. Pasture pests. In: Scott RR ed. New Zealand pest and beneficial insects. Lincoln University College of Agriculture, Canterbury, New Zealand. Pp. 129-142.

Jackson TA, Huger AM, Glare TR 1993. Pathology of amber disease in the New Zealand grass grub, Costelytra zealandica (Coleoptera: Scarabaeidae). Journal of Invertebrate Pathology 61: 123-130.

O'Callaghan M, Jackson TA 1993. Isolation and enumeration of Serratia entomophila - a bacterial pathogen of the New Zealand grass grub, Costelytra zealandica. Journal of Applied Bacteriology 75: 307-314.

Swaminathan J, Jackson TA 2008. Agent stabilisation and delivery process and product. Patent No. NZ 560574, PCT/NZ2008/000299, WO2009061221A2. Encoate Limited. c/AgResearch Ltd, East Street, Ruakura Campus, Hamilton, New Zealand.

van Toor R 1996. Grass grub. Biology, detection and integrated control in pasture. AgReference No 3. AgResearch, Hamilton, New Zealand [ISSN 1173-2768].

Wright DA, Swaminathan J, Blaser M, Jackson TA 2005. Carrot seed coating with bacteria for seedling protection from grass grub damage. New Zealand Plant Protection 58: 229-233.

Young SD, Townsend RJ, O'Callaghan M 2009. Bacterial entomopathogens improve cereal establishment in the presence of grass grub larvae. New Zealand Plant Protection 62: 1-6. 